\title{
Staphylococcus rostri sp. nov., a haemolytic bacterium isolated from the noses of healthy pigs
}

Correspondence

Vincent Perreten

vincent.perreten@vbi.unibe.ch

\section{Andrea Riesen and Vincent Perreten}

\author{
Institute of Veterinary Bacteriology, University of Berne, CH-3001 Berne, Switzerland
}

In recent years, public health concerns have arisen when pigs were reported to harbour meticillin-resistant Staphylococcus aureus (MRSA) in their nasal cavities (de Neeling et al., 2007; Guardabassi et al., 2007; Khanna et al., 2008). MRSA are characterized by the presence of the meticillin resistance gene mecA, which confers resistance to all $\beta$ lactam antibiotics (Deurenberg \& Stobberingh, 2009). They are one of the leading causes of nosocomial and community-acquired infections worldwide (de Lencastre et al., 2007; Deurenberg \& Stobberingh, 2009). In general, $S$. aureus and other staphylococci belong to the normal skin flora of the host and have been found in many animal species (Götz et al., 2006). At the time of writing, 51 different Staphylococcus taxa have been described.

Abbreviation: MRSA, meticillin-resistant Staphylococcus aureus.

The GenBank/EMBL/DDBJ accession numbers for the $16 \mathrm{~S}$ rRNA, dnaJ, $h s p 60$, rpoB, sodA and tarA gene sequences of strain ARI $262^{\top}$ are FM242137, FM244714, FM244716, FM242139 FM242138 and FN433126, respectively, and those of strain ARI 602 are AM989462, FM244715, FM244717, AM989464, AM989463 and FN433127, respectively.

Neighbour-joining trees based on partial $\operatorname{sod} A, \operatorname{rpoB}$, hsp60 and dnaJ sequences are available as supplementary material with the online version of this paper.
While MRSA were not found during a surveillance study in Switzerland that screened pigs for the presence of staphylococci (Riesen \& Perreten, 2009), a third of the sampled animals were found to carry in their noses bacteria that displayed $\alpha$-haemolysis on sheep-blood agar. The isolates were Gram-stain-positive cocci, catalase-positive and coagulase-negative. Sequence analysis of the $16 \mathrm{~S}$ rRNA gene revealed that they belonged to the genus Staphylococcus, but differed from the other 51 known Staphylococcus species and subspecies (Fig. 1). The isolates were further characterized using $16 \mathrm{~S}$ rRNA, sodA, rpoB, dnaJ and hsp60 gene sequence comparison and phenotypic properties. The fatty acid profile, cell-wall structure, menaquinone pattern and DNA $\mathrm{G}+\mathrm{C}$ content and DNA-DNA hybridization were determined using strains ARI $262^{\mathrm{T}}$ and ARI 602 following the recommendations for the description of novel staphylococcal species (Freney et al., 1999).

Bacteria were isolated from the nasal cavities of pigs [Swiss Large White (Edelschwein)] using swabs (Oxoid) at the slaughterhouse. Swabs were placed directly into tubes containing Mueller-Hinton II broth (Becton Dickinson) supplemented with $6.5 \% \mathrm{NaCl}$ and inoculated at $37{ }^{\circ} \mathrm{C}$ for $24 \mathrm{~h}$ under agitation. From there, a loopful was spread onto tryptone soy agar plates containing $5 \%$ sheep blood (TSA-SB; Oxoid). The plates were incubated at $37{ }^{\circ} \mathrm{C}$ for $24 \mathrm{~h}$. All strains displaying 


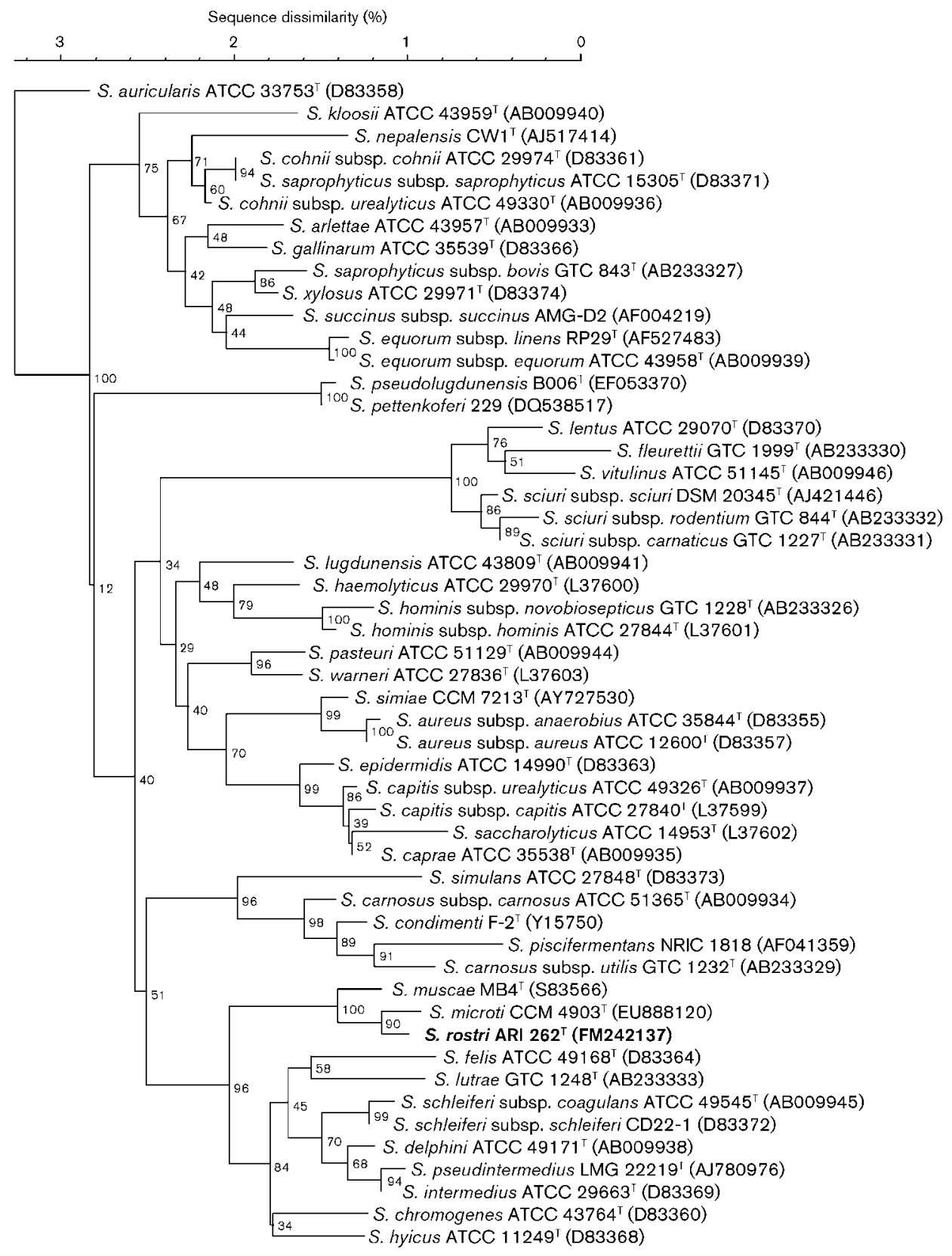

Fig. 1. Cluster analysis of partial $16 \mathrm{~S}$ rRNA gene sequences (1413 bp) of Staphylococcus rostri sp. nov. ARI $262^{\top}$ compared with strains of 51 taxa of the genus Staphylococcus. The tree was generated by neighbour-joining [Pairwise (OG: 100\%, UG: 0\%), Gapcost: 0\%] and Jukes-Cantor correction using Bionumerics 5.10 (Applied Maths). Bootstrap values are shown at each node as percentages of 1000 replicates. GenBank/EMBL/DDBJ accession numbers are displayed in parentheses.

$\alpha$ - or $\alpha$ - $\beta$-haemolysis on TSA-SB plates were spread onto chromagar $S$. aureus ID (SAID; bioMérieux), a selective agar that reveals $\alpha$-glucosidase activity, allowing the distinction of S. aureus from the majority of other staphylococci (Perry et al., 2003). On this agar, S. aureus colonies appear green, while other staphylococci display another colour.

Of 54 herds tested, $31(57.4 \%)$ contained pigs that harboured staphylococci with colonies that displayed $\alpha$ - haemolysis on TSA-SB and appeared pink on SAID agar. Twenty of these isolates, each originating from pigs of a different herd, were selected randomly and further identified and characterized.

Partial nucleotide sequences of the 16S rRNA gene (1413 nt) were determined for the 20 strains as described previously (Kuhnert et al., 2002). These strains shared identical 16S rRNA gene sequences, indicating that they are 
all likely to belong to the same species. DNA sequences were also determined for specific conserved markers present within the genes sodA (Poyart et al., 2001), rpoB (Drancourt \& Raoult, 2002), hsp60 (Kwok \& Chow, 2003) and dnaJ (Shah et al., 2007). These markers have been shown to allow good discrimination between Staphylococcus species. Sequence alignment of these markers revealed two different subtypes among the 20 strains. The two subtypes shared identical $16 \mathrm{~S}$ rRNA gene and $\operatorname{sodA}$ sequences, but differed from each other in their $r p o B$ (99.2\% similarity), dnaJ (98.8\%) and hsp60 (98.2\%) sequences. A parallel study that determined the antibiotic resistance profiles and genetic relatedness of 105 isolates of the novel species also revealed the presence of two specific genotypes, as determined by $h s p 60$ sequence analysis and PFGE (Stegmann \& Perreten, 2010). Therefore, one representative of each of these genotypes, strains ARI $262^{\mathrm{T}}$ and ARI 602, was used for characterization.

DNA sequences of the $16 \mathrm{~S}$ rRNA, rpoB, sodA, dnaJ and hsp60 genes showed that the novel strains also differ from Staphylococcus microti, a bacterium originally isolated from voles (Nováková et al., 2010), and Staphylococcus muscae, originally isolated from flies (Hájek et al., 1992), which shared the highest sequence identity. The 16S rRNA gene sequences of strains ARI $262^{\mathrm{T}}$ and ARI 602 showed $99.6 \%$ identity to the sequence of $S$. microti CCM $4903^{\mathrm{T}}$ and $96.2 \%$ identity to the sequence of S. muscae MB4 ${ }^{\mathrm{T}}$ (Fig. 1). sodA fragments from strains ARI $262^{\mathrm{T}}$ and ARI 602 showed $91.8 \%$ sequence identity to the sequence of $S$. microti CCM $4903^{\mathrm{T}}$ and $87.6 \%$ identity to the sequence of S. muscae CIP $103641^{\mathrm{T}}$ (Supplementary Fig. S1, available in IJSEM Online). Sequenced $r p o B$ fragments of strains ARI $262^{\mathrm{T}}$ and ARI $602^{\mathrm{T}}$ showed 94.1 and $93.8 \%$ identity, respectively, to that of S. microti CCM $4903^{\mathrm{T}}$ and 91.3 and $91.1 \%$ identity, respectively, to that of $S$. muscae CIP $103641^{\mathrm{T}}$ (Supplementary Fig. S2). The sequenced $h s p 60$ fragments of strains ARI $262^{\mathrm{T}}$ and ARI 602 displayed 91.1 and $91.3 \%$ identity, respectively, to that of $S$. microti CCM $4903^{\mathrm{T}}$ and 87.7 and $87.9 \%$ identity, respectively, to that of S. muscae DSM $7068^{\mathrm{T}}$ (Supplementary Fig. S3) and the sequenced dnaJ fragments of strains ARI $262^{\mathrm{T}}$ and ARI 602 displayed 88.2 and $88.5 \%$ identity, respectively, to that of S. microti CCM $4903^{\mathrm{T}}$ and 84.3 and $84.4 \%$ identity, respectively, to that of S. muscae GTC $704^{\mathrm{T}}$ (Supplementary Fig. S4).

The novel strains also differed from the type strains of $S$. microti and S. muscae by DNA-DNA hybridization, as determined by the DSMZ (Deutsche Sammlung von Mikroorganismen und Zellkulturen $\mathrm{GmbH}$, Braunschweig, Germany). DNA-DNA hybridization was performed with DNA isolated using a French pressure cell (Thermo Spectronic) and purified by chromatography on hydroxyapatite as described previously (Cashion et al., 1977). DNA-DNA hybridization was carried out at $63{ }^{\circ} \mathrm{C}$ as described by De Ley et al. (1970) under consideration of the modifications described by Huß et al. (1983) using a model Cary 100 Bio UV/Vis spectrometer equipped with a
Peltier-thermostatted $6 \times 6$ multicell changer and a temperature controller with in-situ temperature probe (Varian). A threshold value of $70 \%$ DNA-DNA relatedness for the definition of bacterial species was considered by the ad hoc committee (Wayne et al., 1987). Strains ARI $262^{\mathrm{T}}$ and ARI 602 belong to the same species, with a DNA-DNA relatedness of $83.4 \%$. Neither strain belongs to the species S. microti (20.1 and $30.0 \%$ relatedness, respectively, to $S$. microti CCM $4903^{\mathrm{T}}$ ) or S. muscae (31.9 and $36.8 \%$ relatedness to $S$. muscae DSM $7068^{\mathrm{T}}$ ), which are the closest relatives by $16 \mathrm{~S}$ rRNA, sodA, dnaJ and $h s p 60$ sequence comparison. The novel strains shared only $19 \%$ DNA-DNA relatedness with Staphylococcus hyicus DSM 20459 ${ }^{\mathrm{T}}$, another pig strain.

DNA G + C contents, menaquinone profile, peptidoglycan structure and fatty acid composition were determined at the DSMZ. DNA G $+\mathrm{C}$ contents of strains ARI $262^{\mathrm{T}}$ and ARI 602 were 38.8 and $39.0 \mathrm{~mol} \%$, respectively, as determined by HPLC. The G $+\mathrm{C}$ contents are within the range reported for other Staphylococcus species (3340 mol\%; Götz et al., 2006). The fatty acid composition was determined by gas chromatography (http://www.midiinc.com). Fatty acids iso- $\mathrm{C}_{15: 0}$, anteiso- $\mathrm{C}_{15: 0}$ and iso- $\mathrm{C}_{17: 0}$ were the most common fatty acids in strains ARI $262^{\mathrm{T}}$ and ARI 602 (Table 1). The fatty acid composition was similar to that of S. microti $4005-\mathrm{LJ}(\mathrm{m})^{\mathrm{T}}$ and differed from that of S. muscae $\mathrm{MB}^{\mathrm{T}}$, in which iso- $\mathrm{C}_{15: 0}, \mathrm{C}_{16: 0}$ and $\mathrm{C}_{18: 0}$ were the most prevalent (Table 1). The peptidoglycan structure of strains ARI $262^{\mathrm{T}}$ and ARI 602 was determined as

Table 1. Fatty acid compositions of strains ARI $262^{\top}$ and $A R I$ 602, S. microti 4005-LJ(m) ${ }^{\top}$ and S. muscae $\mathrm{MB}^{\top}$

Data for S. microti $4005-\mathrm{LJ}(\mathrm{m})^{\mathrm{T}}$ and S. muscae $\mathrm{MB}^{\mathrm{T}}$ were taken from Nováková et al. (2010) and Hájek et al. (1992), respectively. Values are percentages of total fatty acids. NR, Not reported; -, not detected.

\begin{tabular}{|c|c|c|c|c|}
\hline Fatty acid & ARI $262^{T}$ & ARI 602 & $\begin{array}{c}\text { S. microti } \\
4005-\mathrm{LJ}(\mathrm{m})^{\mathrm{T}}\end{array}$ & $\begin{array}{l}\text { S. muscae } \\
\text { MB }^{\mathrm{T}}\end{array}$ \\
\hline iso- $\mathrm{C}_{13: 0}$ & 0.72 & 0.80 & 0.5 & 1.1 \\
\hline iso- $\mathrm{C}_{14: 0}$ & 0.38 & 0.71 & - & NR \\
\hline $\mathrm{C}_{14: 0}$ & 1.39 & 3.15 & 0.6 & 3.7 \\
\hline iso- $\mathrm{C}_{15: 0}$ & 43.65 & 36.79 & 51.7 & 40.9 \\
\hline anteiso- $\mathrm{C}_{15: 0}$ & 19.20 & 15.36 & 12.6 & 1.0 \\
\hline $\mathrm{C}_{15: 0}$ & 0.21 & 0.53 & - & NR \\
\hline iso- $\mathrm{C}_{16: 0}$ & 0.70 & 0.95 & 0.5 & NR \\
\hline $\mathrm{C}_{16: 0}$ & 6.24 & 9.11 & 3.7 & 14.8 \\
\hline iso- $\mathrm{C}_{17: 0}$ & 8.04 & 8.43 & 13.7 & 5.8 \\
\hline anteiso- $\mathrm{C}_{17: 0}$ & 5.70 & 5.69 & 3.9 & 1.9 \\
\hline $\mathrm{C}_{17: 0}$ & 0.36 & 0.49 & - & NR \\
\hline iso- $\mathrm{C}_{18: 0}$ & 0.07 & - & - & NR \\
\hline $\mathrm{C}_{18: 0}$ & 7.50 & 9.08 & 4.4 & 10.7 \\
\hline iso- $\mathrm{C}_{19: 0}$ & 0.76 & 1.07 & 1.1 & 1.0 \\
\hline anteiso- $\mathrm{C}_{19: 0}$ & 0.41 & 0.57 & - & NR \\
\hline $\mathrm{C}_{19: 0}$ & 0.39 & 0.50 & - & NR \\
\hline $\mathrm{C}_{20: 0}$ & 4.26 & 6.77 & 1.2 & 10.1 \\
\hline
\end{tabular}


described by Schleifer (1985) and Schleifer \& Kandler (1972) with the modification that TLC on cellulose was applied instead of paper chromatography. Quantitative analysis of amino acids was performed after derivatization by GC and GC/MS according to MacKenzie (1987).

Total hydrolysates $\left(4 \mathrm{M} \mathrm{HCl}, 16 \mathrm{~h}, 100{ }^{\circ} \mathrm{C}\right)$ of the peptidoglycan contained the amino acids Lys, Ala, Gly, Ser and Glu in molar ratios of about $1.0: 1.8: 3.1: 0.9: 1.0$ (ARI $262^{\mathrm{T}}$ ) and $1.1: 1.7: 3.2: 1.1: 1.0$ (ARI 602). Partial hydrolysates $\left(4 \mathrm{M} \mathrm{HCl}, 0.75 \mathrm{~h}, 100{ }^{\circ} \mathrm{C}\right)$ of the peptidoglycan of the two strains contained (in addition to the amino acids) the peptides L-Ala $\rightarrow \mathrm{D}-\mathrm{Glu}, \mathrm{Gly} \rightarrow \mathrm{Gly}, \mathrm{D}-\mathrm{Ala} \rightarrow \mathrm{Gly}$, Gly $\rightarrow$ L-Lys, L-Lys $\rightarrow$ D-Ala and Gly $\rightarrow$ L-Lys $\rightarrow$ D-Ala. From these data, it was concluded that strains ARI $262^{\mathrm{T}}$ and ARI 602 show the peptidoglycan type A3 $\alpha$ L-Lys-Gly ${ }_{2}-\mathrm{L}-\mathrm{Ser}-$ Gly (type A11.3) according to the system proposed by Schleifer \& Kandler (1972) for the characterization and representation of peptidoglycan types (http://www.dsmz. $\mathrm{de} /$ microorganisms/main.php?content_id=35).

The presence of teichoic acid in the novel strains was determined by sequencing the $N$-acetyl- $\beta$-D-mannosaminyltransferase gene tarA, which is involved in ribitol teichoic acid biosynthesis (Qian et al., 2006). The tarA gene was amplified from strains ARI $262^{\mathrm{T}}$ and ARI 602 by PCR and subsequently sequenced using degenerate primers tarA-F-univ ( $5^{\prime}$-AAIITITTTITIGTIACIGCIAAICCIGA) and tarA-R-univ (5'-TTCIAIIGAICCICCIACICCCAT) designed from the consensus sequence of aligned tarA genes from S. aureus MRSA252 (GenBank accession no. BX571856), Staphylococcus capitis SK14 (ACFR01000002), Staphylococcus warneri L37603 (ACPZ01000027), Staphylococcus hominis SK119 (ACLP 01000017), Staphylococcus epidermidis ATCC 12228 (AE015929), Staphylococcus haemolyticus JCSC1435 (AP006716), Staphylococcus saprophyticus subsp. saprophyticus ATCC $15305^{\mathrm{T}}$ (AP008934) and Staphylococcus carnosus subsp. carnosus TM300 (AM295250). PCR was performed using Taq polymerase following the manufacturer's instructions (Roche Diagnostics). PCR conditions consisted of an initial denaturation step at $94{ }^{\circ} \mathrm{C}$ for $3 \mathrm{~min}$, followed by 35 cycles of denaturation at $94{ }^{\circ} \mathrm{C}$ for $30 \mathrm{~s}$, annealing at $37^{\circ} \mathrm{C}$ for $30 \mathrm{~s}$ and elongation at $72{ }^{\circ} \mathrm{C}$ for 50 s. PCR products were sequenced on an ABI Prism 3100 Genetic Analyzer (Applied Biosystems).

Respiratory lipoquinones were extracted from $100 \mathrm{mg}$ freeze-dried cell material based on the two-stage method described by Tindall (1990a, b). Respiratory quinones were extracted using methanol/hexane (Tindall, 1990a, b). Respiratory lipoquinones were separated into their different classes (menaquinones and ubiquinones) by TLC on silica gel (Macherey-Nagel art. no. 805023 ), using hexane/ tert-butyl methyl ether $(9: 1, \mathrm{v} / \mathrm{v})$ as solvent. UV-absorbing bands corresponding to menaquinones or ubiquinones were removed from the plate and analysed further by HPLC. This step was carried out on an LDC Analytical HPLC (Thermo Separation Products) fitted with a reversed-phase column (Macherey-Nagel; $2 \times 125 \mathrm{~mm}$, $3 \mu \mathrm{m}, \mathrm{RP} 18)$ using methanol as the eluent. Respiratory lipoquinones were detected at $269 \mathrm{~nm}$. Strains ARI $262^{\mathrm{T}}$ and ARI 602 contained menaquinone 7 (MK-7) as the major component (79\%) and smaller proportions of MK-6 (4 and $7 \%$, respectively), as well as an unidentified menaquinone (possible dimethylmenaquinone 7). Similar menaquinone profiles have been reported in S. microti and S. muscae (Nováková et al., 2010).

Phylogenetic relationships of the novel strains and other staphylococcal species were determined using Bionumerics 5.10 (Applied Maths), analysing sequences of the 16S rRNA gene (Drancourt \& Raoult, 2002), sodA (Poyart et al., 2001), rpoB (Drancourt \& Raoult, 2002), dnaJ (Shah et al., 2007) and hsp60 (Kwok \& Chow, 2003). The trees were generated by neighbour-joining [Pairwise (OG: $100 \%$, UG: $0 \%$ ); Gapcost: $0 \%$ ] using the Jukes-Cantor correction. Bootstrap values were determined from 1000 replications. The phylogenetic trees showed that the novel strains cluster within the S. hyicus-S. intermedius group (Shah et al., 2007) and are related to S. microti and S. muscae (Fig. 1 and Supplementary Figs S1-S4).

Phenotypic characterization of strains ARI $262^{\mathrm{T}}$ and ARI 602, S. microti CCM $4903^{\mathrm{T}}$ and S. muscae DSM $7068^{\mathrm{T}}$ was achieved using ID 32 STAPH (bioMérieux) following the manufacturer's recommendations. Contradictory results to those published for S. microti CCM $4903^{\mathrm{T}}$ by Nováková et al. (2010) were obtained for $\beta$-galactosidase and arginine arylamidase using the same strain and the same system. $S$. microti CCM $4903^{\mathrm{T}}$ appeared to be negative for the production of these two enzymes in our tests. These criteria cannot be used to differentiate between these two species. However, strains ARI $262^{\mathrm{T}}$ and ARI 602 can be differentiated from S. microti CCM $4903^{\mathrm{T}}$ by the absence of mannose fermentation and alanine arylamidase. Strains ARI $262^{\mathrm{T}}$ and ARI 602 can be differentiated from S. muscae DSM $7068^{\mathrm{T}}$ by the absence of $\beta$-glucuronidase and production of alkaline phosphatase (Table 2). To confirm the results obtained with ID 32 STAPH (bioMérieux), mannose fermentation was additionally tested in bromothymol blue broth containing $0.5 \%$ mannose; $S$. microti CCM $4903^{\mathrm{T}}$ was positive, whereas strains ARI $262^{\mathrm{T}}$ and ARI 602 remained negative after $18 \mathrm{~h}$ of incubation at $37{ }^{\circ} \mathrm{C}$. $\beta$-Galactosidase activity was tested on MuellerHinton plates containing $40 \mu \mathrm{g}$ 5-bromo-4-chloro-3indolyl $\beta$-D-galactopyranoside (X-Gal) $\mathrm{ml}^{-1}$. Alanine arylamidase was tested using Vitek 2 (bioMérieux). $\beta$ Glucuronidase activity was tested on glucuronidase chromagar CPS ID3 (bioMérieux); colonies of the novel strains appeared white, whereas colonies of S. muscae DSM $7068^{\mathrm{T}}$ appeared red. Alkaline phosphatase was confirmed on Mueller-Hinton agar containing $0.01 \%$ phenolphthalein diphosphate tetrasodium salt and exposing colonies to ammonia vapour (Holding \& Collee, 1971). Colonies that produced phosphatase turned pink. Aesculin hydrolysis was determined on aesculin agar (Bio-Rad). Catalase activity was determined by direct application of a single 


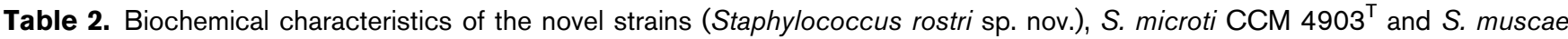
DSM $7068^{\top}$

Novel strains: 1 , ARI 262 ${ }^{\mathrm{T}}$; 2 , ARI 311; 3, ARI 411; 4, ARI 522; 5, ARI 731; 6, ARI 1211; 7, ARI 2162; 8, ARI 2231; 9, ARI 2701; 10, ARI 2981; 11, ARI 602; 12, ARI 161; 13, ARI 791; 14, ARI 841; 15, ARI 921; 16, ARI 991; 17, ARI 1052; 18, ARI 1101; 19, ARI 1301; 20, ARI 2491. Data for S. microti CCM $4903^{\mathrm{T}}$ were taken from Nováková et al. (2010). Strains $1-10$ are related to type strain ARI $262^{\mathrm{T}}$ and strains $10-20$ are related to ARI 602 , as determined by $h s p 60$, dnaJ and $r p o B$ sequencing. +, Positive; \pm , weakly positive reaction (may appear negative when determined with ID 32 STAPH); (+), negative in this study, in contrast to results of Nováková et al. (2010); -, negative. All strains were negative for oxidase, urease and ornithine decarboxylase activities, novobiocin resistance and acid production from maltose, D-mannitol, raffinose, D-ribose, cellobiose, turanose and L-arabinose. All strains were positive for reduction of nitrate, pyrrolidonyl arylamidase activity and acid production from D-glucose, D-fructose and sucrose.

\begin{tabular}{|c|c|c|c|c|c|c|c|c|c|c|c|c|c|c|c|c|c|c|c|c|c|c|}
\hline Characteristic & 1 & 2 & 3 & 4 & 5 & 6 & 7 & 8 & 9 & 10 & 11 & 12 & 13 & 14 & 15 & 16 & 17 & 18 & 19 & 20 & $\begin{array}{c}\text { S. muscae } \\
\text { DSM } 7068^{\mathrm{T}}\end{array}$ & $\begin{array}{l}\text { S. microti } \\
{\text { CCM } 4903^{\mathrm{T}}}^{\text {CCM }}\end{array}$ \\
\hline Arginine dihydrolase & + & + & + & + & + & + & + & + & + & + & - & + & - & - & + & - & + & + & + & + & - & - \\
\hline $\begin{array}{l}\text { Hydrolysis of aesculin } \\
\text { Acid production from: }\end{array}$ & \pm & \pm & \pm & \pm & \pm & \pm & \pm & \pm & \pm & \pm & \pm & \pm & \pm & \pm & \pm & - & \pm & \pm & \pm & \pm & - & + \\
\hline Trehalose & + & + & + & + & + & + & + & + & + & + & + & + & - & - & + & + & + & + & + & + & + & + \\
\hline$N$-Acetylglucosamine & + & - & - & + & + & + & - & + & + & + & + & + & + & + & + & + & + & + & + & + & + & + \\
\hline Production of acetoin & - & - & - & - & - & - & - & - & - & - & - & - & - & - & - & - & - & - & - & - & - & \pm \\
\hline$\beta$-Galactosidase & - & - & - & - & - & - & - & - & - & - & - & - & - & - & - & - & - & - & - & - & - & $(+)$ \\
\hline$\beta$-Glucuronidase & - & - & - & - & - & - & - & - & - & - & - & - & - & - & - & - & - & - & - & - & + & - \\
\hline Arginine arylamidase & - & - & - & - & - & - & - & - & - & - & - & - & - & - & - & - & - & - & - & - & - & $(+)$ \\
\hline Alanine arylamidase & - & - & - & - & - & - & - & - & - & - & - & - & - & - & - & - & - & - & - & - & - & + \\
\hline Alkaline phosphatase & + & + & + & + & + & + & + & + & + & + & + & + & + & + & + & + & + & + & + & + & - & + \\
\hline
\end{tabular}

drop of $3 \% \mathrm{H}_{2} \mathrm{O}_{2}$ to the cells. DNase activity was tested on $\mathrm{BD}$ BBL DNase test agar. Thermonuclease activity was determined by spotting $20 \mu \mathrm{l}$ filtered overnight culture supernatant on BD BBL DNase test agar subsequently incubated for $2 \mathrm{~h}$ at $60{ }^{\circ} \mathrm{C}$ and flooded with $1 \mathrm{M} \mathrm{HCl}$. Coagulase was determined using rabbit plasma (BD BBL coagulase plasmas). Clumping factor, Protein A and groupspecific antigen bound to the $S$. aureus-specific peripheral structure were tested using the rapid latex agglutination tests Slidex Staph Plus (bioMérieux) and Pastorex Staph Plus (Bio-Rad). Cytochrome oxidase was tested using BD BBL oxidase reagent droppers. Growth assays with different salt concentrations $(6.5,9$ and $12 \%, \mathrm{w} / \mathrm{v}, \mathrm{NaCl})$ and at 15 , 37 and $43{ }^{\circ} \mathrm{C}$ were performed in BD Bacto brain heart infusion. Anaerobic growth was tested in thioglycolate. The lysostaphin test was performed using cells diluted in PBS to $\mathrm{OD}_{600}$ 0.8. After addition of $25 \mu \mathrm{g}$ lysostaphin $\mathrm{ml}^{-1}$ (Sigma-Aldrich), cells were incubated for $1 \mathrm{~h}$ at $37^{\circ} \mathrm{C}$ and lysis was measured spectrophotometrically at $\mathrm{OD}_{600}$. The diameter of cells of the novel strains was determined by scanning electron microscopy $[\times 10000$ magnification; DSM 982 Gemini (Zeiss Oberkochen)] by K. Kühni Boghenbor and M. H. Stoffel (Division of Veterinary Anatomy, University of Berne, Switzerland).

The novel strains can be distinguished from other species of the genus Staphylococcus by phenotypic and genetic criteria. On the basis of these distinct characteristics, we propose to classify these strains within a novel Staphylococcus species, Staphylococcus rostri sp. nov.

\section{Description of Staphylococcus rostri sp. nov.}

Staphylococcus rostri (ros'tri. L. n. rostrum the snout of a swine; L. gen. n. rostri of a pig's snout).

Cells are Gram-stain-positive, non-motile cocci (0.5$1.1 \mu \mathrm{m})$. After $24 \mathrm{~h}$ of growth at $37^{\circ} \mathrm{C}$, colonies reach $2 \mathrm{~mm}$ in diameter, are slightly convex, smooth, glossy and opaque white and display $\alpha$-haemolysis on sheep-blood (TSA-SB) agar. Strains have a positive Christie-AtkinsMunch-Petersen (CAMP) reaction with $\beta$-toxin-producing $S$. aureus JA32, indicating that the $\alpha$-haemolysis that appears on sheep-blood agar is generated by the production of a $\delta$-haemolysin (Freney et al., 1999). Grows aerobically and anaerobically. Grows with 9 and $12 \%$ $\mathrm{NaCl}(\mathrm{w} / \mathrm{v})$ and at $43{ }^{\circ} \mathrm{C}$, but not at 45 or $15{ }^{\circ} \mathrm{C}$. Catalasepositive, oxidase-negative and does not coagulate rabbit plasma. Does not agglutinate with Slidex or Pastorex, which identify S. aureus. Hydrolyses DNA at $37^{\circ} \mathrm{C}$, generating a 2-5 $\mathrm{mm}$ degradation halo, but does not produced thermostable nucleases. Does not produce urease, ornithine decarboxylase, $\beta$-galactosidase, $\beta$-glucuronidase, acetoin or arginine arylamidase. Positive for aerobic production of acids from D-glucose, D-fructose and sucrose, activities of pyrrolidonyl arylamidase, alanine arylamidase and alkaline phosphatase and reduction of 
nitrate. No acid is produced from D-mannose, maltose, raffinose, D-ribose, D-mannitol, turanose, D-arabinose or cellobiose. Variable reactions are obtained for acid production from lactose ( 3 of 20 strains negative), trehalose ( 2 of 20 negative) and $\mathrm{N}$-acetylglucosamine (3 of 20 negative). Variable reactions are also obtained for the production of arginine dihydrolase ( 4 of 20 negative). Hydrolyses aesculin weakly (one strain negative, 19 weakly positive). All known strains are susceptible to novobiocin and lysostaphin.

The type strain is ARI $262^{\mathrm{T}}\left(=\mathrm{DSM} 21968^{\mathrm{T}}=\mathrm{CCUG}\right.$ $\left.57266^{\mathrm{T}}\right)$. Strain ARI $602(=\mathrm{DSM} 21969=$ CCUG 57267) is a reference strain. These strains and 18 other strains were isolated from the snouts of pigs.

\section{Acknowledgements}

We thank Alexandra Rossano, Ramona Stegmann and Andreas Thomann (Institute of Veterinary Bacteriology, University of Berne, Switzerland) and Martin Sievers [Zurich University of Applied Sciences (ZHAW), Wädenswil, Switzerland] for technical assistance or advice and Ivo Sedláček (Institute of Experimental Biology, Masaryk University, Czech Republic) for providing S. microti CCM $4903^{\mathrm{T}}$.

\section{References}

Cashion, P., Holder-Franklin, M. A., McCully, J. \& Franklin, M. (1977). A rapid method for the base ratio determination of bacterial DNA. Anal Biochem 81, 461-466.

de Lencastre, H., Oliveira, D. \& Tomasz, A. (2007). Antibiotic resistant Staphylococcus aureus: a paradigm of adaptive power. Curr Opin Microbiol 10, 428-435.

De Ley, J., Cattoir, H. \& Reynaerts, A. (1970). The quantitative measurement of DNA hybridization from renaturation rates. Eur $J$ Biochem 12, 133-142.

de Neeling, A. J., van den Broek, M. J. M., Spalburg, E. C., van Santen-Verheuvel, M. G., Dam-Deisz, W. D. C., Boshuizen, H. C., van de Giessen, A. W., van Duijkeren, E. \& Huijsdens, X. W. (2007). High prevalence of methicillin resistant Staphylococcus aureus in pigs. Vet Microbiol 122, 366-372.

Deurenberg, R. H. \& Stobberingh, E. E. (2009). The molecular evolution of hospital- and community-associated methicillin-resistant Staphylococcus aureus. Curr Mol Med 9, 100-115.

Drancourt, M. \& Raoult, D. (2002). rpoB gene sequence-based identification of Staphylococcus species. J Clin Microbiol 40, 1333-1338.

Freney, J., Kloos, W. E., Hajek, V., Webster, J. A., Bes, M., Brun, Y. \& Vernozy-Rozand, C. (1999). Recommended minimal standards for description of new staphylococcal species. Int J Syst Bacteriol 49, 489-502.

Götz, F., Bannerman, T. \& Schleifer, K.-H. (2006). The genera Staphylococcus and Macrococcus. In The Prokaryotes, 3rd edn, vol. 4, pp. 5-75. Edited by M. Dworkin, S. Falkow, E. Rosenberg, K. H. Schleifer \& E. Stackebrandt. New York: Springer.

Guardabassi, L., Stegger, M. \& Skov, R. (2007). Retrospective detection of methicillin resistant and susceptible Staphylococcus aureus ST398 in Danish slaughter pigs. Vet Microbiol 122, 384-386.

Hájek, V., Ludwig, W., Schleifer, K. H., Springer, N., Zitzelsberger, W., Kroppenstedt, R. M. \& Kocur, M. (1992). Staphylococcus muscae, a new species isolated from flies. Int J Syst Bacteriol 42, 97-101.
Holding, A. J. \& Collee, J. G. (1971). Routine biochemical tests. Methods Microbiol 6A, 1-32.

Huß, V. A. R., Festl, H. \& Schleifer, K. H. (1983). Studies on the spectrophotometric determination of DNA hybridization from renaturation rates. Syst Appl Microbiol 4, 184-192.

Khanna, T., Friendship, R., Dewey, C. \& Weese, J. S. (2008). Methicillin resistant Staphylococcus aureus colonization in pigs and pig farmers. Vet Microbiol 128, 298-303.

Kuhnert, P., Frey, J., Lang, N. P. \& Mayfield, L. (2002). Phylogenetic analysis of Prevotella nigrescens, Prevotella intermedia and Porphyromonas gingivalis clinical strains reveals a clear species clustering. Int J Syst Evol Microbiol 52, 1391-1395.

Kwok, A. Y. C. \& Chow, A. W. (2003). Phylogenetic study of Staphylococcus and Macrococcus species based on partial hsp60 gene sequences. Int J Syst Evol Microbiol 53, 87-92.

MacKenzie, S. L. (1987). Gas chromatographic analysis of amino acids as the N-heptafluorobutyryl isobutyl esters. J Assoc Off Anal Chem 70, 151-160.

Nováková, D., Pantůček, R., Hubálek, Z., Falsen, E., Busse, H.-J., Schumann, P. \& Sedláček, I. (2010). Staphylococcus microti sp. nov., isolated from the common vole (Microtus arvalis). Int J Syst Evol Microbiol 60, 566-573.

Perry, J. D., Rennison, C., Butterworth, L. A., Hopley, A. L. J. \& Gould, F. K. (2003). Evaluation of S. aureus ID, a new chromogenic agar medium for detection of Staphylococcus aureus. J Clin Microbiol 41, 5695-5698.

Poyart, C., Quesne, G., Boumaila, C. \& Trieu-Cuot, P. (2001). Rapid and accurate species-level identification of coagulase-negative staphylococci by using the sodA gene as a target. J Clin Microbiol 39, 4296-4301.

Qian, Z., Yin, Y., Zhang, Y., Lu, L., Li, Y. \& Jiang, Y. (2006). Genomic characterization of ribitol teichoic acid synthesis in Staphylococcus aureus: genes, genomic organization and gene duplication. BMC Genomics 7, 74-85.

Riesen, A. \& Perreten, V. (2009). Antibiotic resistance and genetic diversity in Staphylococcus aureus from slaughter pigs in Switzerland. Schweiz Arch Tierheilkd 151, 425-431.

Schleifer, K. H. (1985). Analysis of the chemical composition and primary structure of murein. Methods Microbiol 18, 123-156.

Schleifer, K. H. \& Kandler, O. (1972). Peptidoglycan types of bacterial cell walls and their taxonomic implications. Bacteriol Rev 36, 407477.

Shah, M. M., lihara, H., Noda, M., Song, S. X., Nhung, P. H., Ohkusu, K., Kawamura, Y. \& Ezaki, T. (2007). dnaJ gene sequence-based assay for species identification and phylogenetic grouping in the genus Staphylococcus. Int J Syst Evol Microbiol 57, 25-30.

Stegmann, R. \& Perreten, V. (2010). Antibiotic resistance profile of Staphylococcus rostri, a new species isolated from healthy pigs. Vet Microbiol (in press). doi:10.1016/j.vetmic.2010.03.015

Tindall, B. J. (1990a). A comparative study of the lipid composition of Halobacterium saccharovorum from various sources. Syst Appl Microbiol 13, 128-130.

Tindall, B. J. (1990b). Lipid composition of Halobacterium lacusprofundi. FEMS Microbiol Lett 66, 199-202.

Wayne, L. G., Brenner, D. J., Colwell, R. R., Grimont, P. A. D., Kandler, O., Krichevsky, M. I., Moore, L. H., Moore, W. E. C., Murray, R. G. E. \& other authors (1987). International Committee on Systematic Bacteriology. Report of the ad hoc committee on reconciliation of approaches to bacterial systematics. Int J Syst Bacteriol 37, 463-464. 